\title{
Highly efficient ZnO/Au Schottky barrier dye-sensitized solar cells: Role of gold nanoparticles on the charge-transfer process
}

\author{
Tanujjal Bora ${ }^{1}$, Htet H. Kyaw ${ }^{1}$, Soumik Sarkar ${ }^{2}$, Samir K. Pal ${ }^{2}$ \\ and Joydeep Dutta ${ }^{* 1}$
}

\section{Full Research Paper}

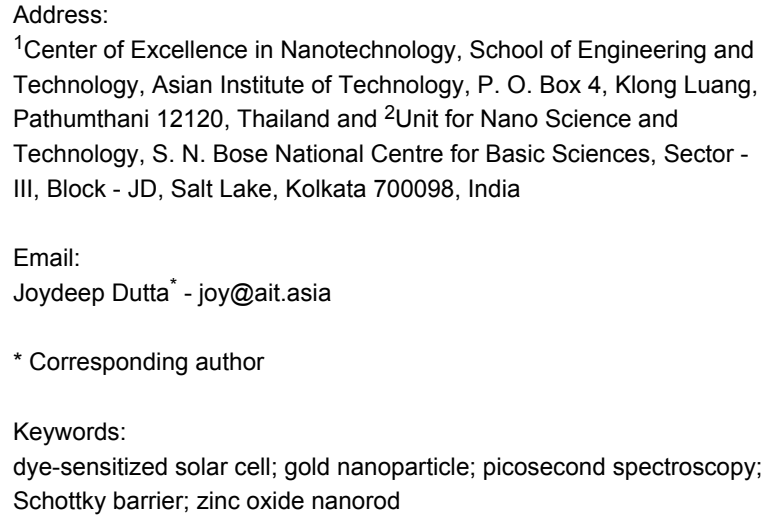

${ }^{1}$ Center of Excellence in Nanotechnology, School of Engineering and Technology, Asian Institute of Technology, P. O. Box 4, Klong Luang, Pathumthani 12120, Thailand and ${ }^{2}$ Unit for Nano Science and Technology, S. N. Bose National Centre for Basic Sciences, Sector III, Block - JD, Salt Lake, Kolkata 700098, India

Email:

Joydeep Dutta* - joy@ait.asia

* Corresponding author

Keywords:

dye-sensitized solar cell; gold nanoparticle; picosecond spectroscopy; Schottky barrier; zinc oxide nanorod

\author{
Beilstein J. Nanotechnol. 2011, 2, 681-690. \\ doi:10.3762/bjnano.2.73 \\ Received: 22 July 2011 \\ Accepted: 21 September 2011 \\ Published: 13 October 2011 \\ Associate Editor: R. Naaman \\ (c) 2011 Bora et al; licensee Beilstein-Institut. \\ License and terms: see end of document.
}

\begin{abstract}
Zinc oxide $(\mathrm{ZnO})$ nanorods decorated with gold $(\mathrm{Au})$ nanoparticles have been synthesized and used to fabricate dye-sensitized solar cells (DSSC). The picosecond-resolved, time-correlated single-photon-count (TCSPC) spectroscopy technique was used to explore the charge-transfer mechanism in the $\mathrm{ZnO} / \mathrm{Au}$-nanocomposite DSSC. Due to the formation of the Schottky barrier at the $\mathrm{ZnO} / \mathrm{Au}$ interface and the higher optical absorptions of the $\mathrm{ZnO} / \mathrm{Au}$ photoelectrodes arising from the surface plasmon absorption of the $\mathrm{Au}$ nanoparticles, enhanced power-conversion efficiency (PCE) of $6.49 \%$ for small-area $\left(0.1 \mathrm{~cm}^{2}\right) \mathrm{ZnO} / \mathrm{Au}$-nanocomposite DSSC was achieved compared to the $5.34 \%$ efficiency of the bare $\mathrm{ZnO}$ nanorod DSSC. The TCSPC studies revealed similar dynamics for the charge transfer from dye molecules to $\mathrm{ZnO}$ both in the presence and absence of Au nanoparticles. A slower fluorescence decay associated with the electron recombination process, observed in the presence of Au nanoparticles, confirmed the blocking of the electron transfer from $\mathrm{ZnO}$ back to the dye or electrolyte by the Schottky barrier formed at the $\mathrm{ZnO} / \mathrm{Au}$ interface. For large area $\operatorname{DSSC}\left(1 \mathrm{~cm}^{2}\right), \sim 130 \%$ enhancement in PCE (from $0.50 \%$ to $1.16 \%$ ) was achieved after incorporation of the Au nanoparticles into the $\mathrm{ZnO}$ nanorods.
\end{abstract}

\section{Introduction}

The dye-sensitized solar cell (DSSC), also known as the Grätzel's cell, has been one of the most extensively studied types of solar cell in the last two decades due to its potential widespread application attributed to lower manufacturing costs [1-3]. Currently one of the major issues hindering the rapid commercialization of DSSCs is their lower conversion effi- 
ciency compared to conventional solar cells. The maximum conversion efficiency of any DSSC reported to date is about $11 \%$ [4]. Due to the presence of various material interfaces in a DSSC, the probability of recombination of the electrons is high at each interface. Law et al. [5] proposed the use of single crystalline zinc oxide $(\mathrm{ZnO})$ nanowires instead of the widely used titanium oxide $\left(\mathrm{TiO}_{2}\right)$ porous thin film to reduce the probability of electron recombination in the DSSC by providing a direct pathway for the electrons to diffuse into the photoelectrode.

Both, $\mathrm{ZnO}$ and $\mathrm{TiO}_{2}$, are wide-band-gap semiconductors with almost comparable band gap ( $3.37 \mathrm{eV}$ and $3.2 \mathrm{eV}$, respectively). Due to the direct band gap, higher exciton energy (60 meV compared to $4 \mathrm{meV}$ for $\mathrm{TiO}_{2}$ ) [6,7], higher electron mobility $\left(200 \mathrm{~cm}^{2} \cdot \mathrm{V}^{-1} \cdot \mathrm{s}^{-1}\right)$ [8] and its ease of synthesis [9], $\mathrm{ZnO}$ is widely employed in various optoelectronic device applications. But, in DSSCs, the recombination of the electrons at the semiconductor/electrolyte interface is still unavoidable. Various attempts to control the recombination at the semiconductor/ electrolyte interface by passivating the electrolyte-exposed part of the metal oxide film by means of different additives in the electrolyte [10-13] or by using the core-shell structure of various metal oxides [14-18] have been reported.

In this work we discuss the use of Au nanoparticles in a DSSC based on $\mathrm{ZnO}$ nanorods to improve the device performance through better charge separation in the photoelectrodes. In this regards, several reports have been previously published [19-23] demonstrating the rapid charge transfer and improved charge separation upon the incorporation of $\mathrm{Au}$ nanoparticles in $\mathrm{ZnO}$ or $\mathrm{TiO}_{2}$-based photoelectrodes ultimately leading to enhanced DSSC performance. But none of these reports clearly explain the exact nature of the charge-transfer mechanism in the presence of $\mathrm{Au}$ nanoparticles. In this present work, through the time-correlated single-photon-count (TCSPC) spectroscopic technique, we explore the charge-transfer process in a $\mathrm{ZnO} / \mathrm{Au}-$ nanocomposite photoelectrode for DSSC application. From the spectroscopic studies, we demonstrate that the enhancement in DSSC performance in the presence of Au nanoparticles with the $\mathrm{ZnO}$ nanorods is primarily due to the formation of a Schottky barrier at the $\mathrm{ZnO} / \mathrm{Au}$ interface and not due to the faster electron injection from dye to $\mathrm{ZnO}$. The effect of $\mathrm{Au}$ nanoparticles on the generation of photocurrent in the $\mathrm{ZnO} / \mathrm{Au}$-nanocomposite-based DSSC was studied for small- $\left(0.1 \mathrm{~cm}^{2}\right)$ as well as large-area $\left(1 \mathrm{~cm}^{2}\right)$ solar cells and the results are compared to those of a $\mathrm{ZnO}$-nanorod DSSC without gold nanoparticles.

\section{Results and Discussion}

The surface morphology of hydrothermally grown $\mathrm{ZnO}$ nanorods and in-situ-deposited Au-nanoparticle-coated $\mathrm{ZnO}$ nanorods is shown in Figure 1, where the diameter of the $\mathrm{ZnO}$ nanorods was found to vary from $\sim 500$ to $700 \mathrm{~nm}$ and the length from $\sim 8$ to $9 \mu \mathrm{m}$. The distribution of the Au nanoparticles over the $\mathrm{ZnO}$-nanorod surface was found to be fairly uniform, as can be observed from Figure 1c. The cross-sectional SEM image indicates (Figure 1d) that the Au nanoparticles grow almost homogeneously over the complete length of the $\mathrm{ZnO}$ nanorods.
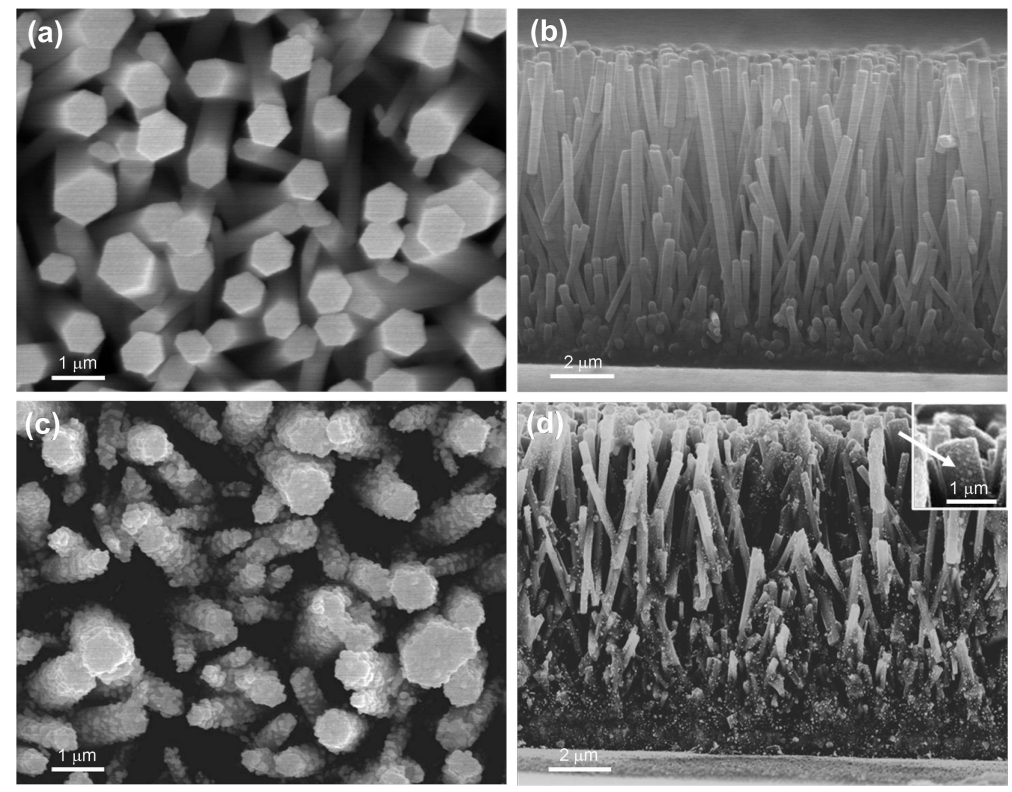

Figure 1: FESEM images showing (a) the top view and (b) the cross-sectional view of the bare ZnO-nanorod photoelectrode, and (c) the top view and (d) the cross-sectional view of the ZnO/Au-nanocomposite photoelectrode. The inset in (d) shows the magnified FESEM image of the Au nanoparticles as synthesized on the surface of the $\mathrm{ZnO}$ nanorods from a $0.01 \mathrm{mM} \mathrm{HAuCl}{ }_{4} \cdot \mathrm{H}_{2} \mathrm{O}$ aq. solution. 
The optical absorptions of the $\mathrm{ZnO}$-nanorod and $\mathrm{ZnO} / \mathrm{Au}$ nanocomposite photoelectrode are shown in Figure 2a. Due to the absorption by surface plasmons in the Au nanoparticles, a higher optical absorption of the $\mathrm{ZnO} / \mathrm{Au}$-nanocomposite photoelectrode near $520 \mathrm{~nm}$ was observed. The optical absorption by the $\mathrm{ZnO} / \mathrm{Au}$ photoelectrode was compared with the absorption by Au nanoparticle colloids (particle size $\sim 20 \mathrm{~nm}$ ), and the results indicated that the Au nanoparticles in both systems were of comparable sizes, which was further verified by TEM imaging. A typical TEM image of the $\mathrm{ZnO} / \mathrm{Au}$-nanorod surface is shown in Figure $2 b$.

The solar cells with $\mathrm{ZnO}$-nanorod and $\mathrm{ZnO} / \mathrm{Au}$-nanocomposite photoelectrodes in the absence of dye N719 were initially prepared in order to study the photovoltaic behavior of the $\mathrm{ZnO} / \mathrm{Au}$-nanocomposite system. The $J-V$ characteristics of these solar cells are shown in Table 1. Upon illumination under a light intensity of $100 \mathrm{~mW} / \mathrm{cm}^{2}$ (1 sun, air mass (AM) $1.5 \mathrm{G}$ ), the bare $\mathrm{ZnO}$-nanorod solar cell exhibited short-circuit current density $\left(J_{\mathrm{sc}}\right)$ of $18.80 \mu \mathrm{A} / \mathrm{cm}^{2}$ and open-circuit voltage $\left(V_{\text {oc }}\right)$ of $0.27 \mathrm{~V}$. On the other hand, the $\mathrm{ZnO} / \mathrm{Au}$-nanocomposite solar cell, under illumination, demonstrated higher $J_{\mathrm{sc}}$ $\left(82.46 \mu \mathrm{A} / \mathrm{cm}^{2}\right)$ as well as $V_{\mathrm{oc}}(0.39 \mathrm{~V})$ compared to the bare $\mathrm{ZnO}$-nanorod solar cell, which is mainly attributed to the higher optical absorption of the $\mathrm{ZnO} / \mathrm{Au}$ photoelectrode due to the absorption by surface plasmons in Au nanoparticles.

In the case of the $\mathrm{ZnO} / \mathrm{Au}$ solar cells without any sensitizer dye molecules, the photoexcited electrons in the Au nanoparticles are transferred to the conduction band $(\mathrm{CB})$ of $\mathrm{ZnO}$, and then diffuse through the $\mathrm{ZnO}$ nanorods towards the conducting fluorine-doped tin oxide (FTO) substrate resulting in higher
Table 1: J-V characteristics of bare $\mathrm{ZnO}$-nanorod and $\mathrm{ZnO} / \mathrm{Au}-$ nanocomposite solar cells in the absence of dye N719, measured at an illumination of 1 sun, AM $1.5 \mathrm{G}\left(100 \mathrm{~mW} / \mathrm{cm}^{2}\right){ }^{a}$

\begin{tabular}{lll}
$\begin{array}{l}J-V \\
\text { parameters }\end{array}$ & $\begin{array}{l}\text { Bare } \mathrm{ZnO} \text {-nanorod } \\
\text { solar cell }\end{array}$ & $\begin{array}{l}\mathrm{ZnO} / \mathrm{Au}- \\
\text { nanocomposite } \\
\text { solar cell }\end{array}$ \\
\hline$V_{\mathrm{oc}}(\mathrm{V})$ & 0.27 & 0.39 \\
$J_{\mathrm{sc}}\left(\mu \mathrm{A} / \mathrm{cm}^{2}\right)$ & 18.80 & 82.46 \\
fill factor, FF (\%) & 30.94 & 52.05 \\
$\eta(\%)$ & 0.002 & 0.017 \\
\hline
\end{tabular}

aThe active area of all the solar cells was maintained at $0.25 \mathrm{~cm}^{2}$ during these experiments.

photocurrent and photovoltage, as observed. The injection of the excited electrons from $\mathrm{Au}$ nanoparticles into the $\mathrm{CB}$ of $\mathrm{ZnO}$ is believed to be facilitated by the existence of the Schottky barrier at the $\mathrm{ZnO} / \mathrm{Au}$ interface, which provides a unidirectional pathway for the electrons from gold to the conduction band of $\mathrm{ZnO}$. Upon injection, the regeneration of the $\mathrm{Au}$ nanoparticles occurs by capturing electrons from the redox electrolyte $\left(\mathrm{I}^{-} / \mathrm{I}_{3}{ }^{-}\right)$present in the cell. Stability of the Au nanoparticles in the $\mathrm{I}^{-} / \mathrm{I}_{3}{ }^{-}$redox electrolyte was tested by measuring the $J-V$ characteristics of the $\mathrm{ZnO} / \mathrm{Au}$ solar cell after $24 \mathrm{~h}$ (data not shown here), and negligible changes in the solar cell performance were observed.

The performance of the solar cell in the presence of the dye was then studied by fabricating three sets of $\mathrm{ZnO}$-nanorod and $\mathrm{ZnO} / \mathrm{Au}$-nanocomposite solar cells, each with dye $\mathrm{N} 719$, and their $J-V$ characteristics were measured under 1 sun, AM $1.5 \mathrm{G}$ illumination; the results are shown in Table 2. In Figure 3a, the
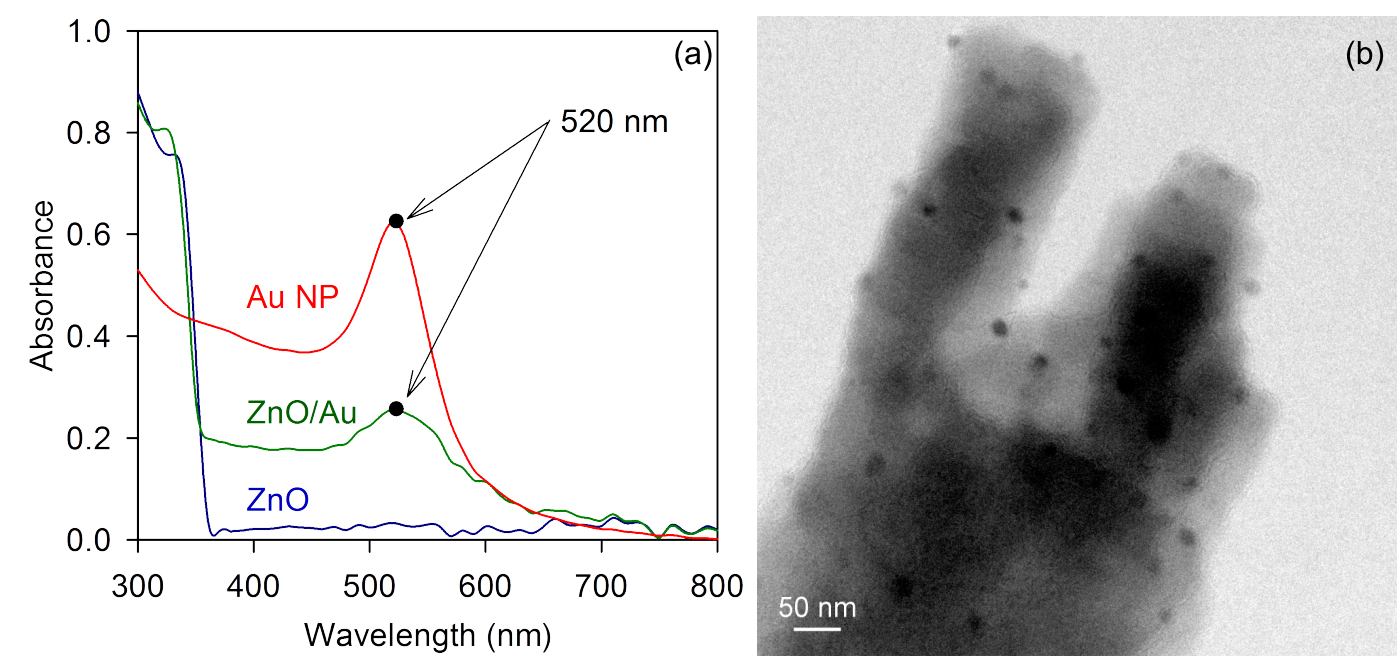

Figure 2: (a) Optical absorption of $\mathrm{ZnO}$ nanorods, $\mathrm{ZnO} / \mathrm{Au}$-nanocomposite photoelectrode and Au-nanoparticle colloid (particle size $\sim 20 \mathrm{~nm}$ ) and (b) TEM image of Au nanoparticles in situ deposited on the surface of a $\mathrm{ZnO}$ nanorod. 


\begin{tabular}{|c|c|c|c|c|c|c|}
\hline \multirow[t]{2}{*}{$J-V$ parameters } & \multicolumn{3}{|c|}{ Bare ZnO-nanorod DSSC } & \multicolumn{3}{|c|}{ ZnO/Au-nanocomposite DSSC } \\
\hline & cell I & cell II & cell III & cell I & cell II & cell III \\
\hline$V_{\text {oc }}(\mathrm{V})$ & 0.67 & 0.67 & 0.67 & 0.67 & 0.65 & 0.66 \\
\hline$J_{\mathrm{sc}}\left(\mathrm{mA} / \mathrm{cm}^{2}\right)$ & 10.98 & 11.01 & 10.84 & 14.89 & 14.28 & 14.45 \\
\hline $\mathrm{FF}(\%)$ & 71.55 & 72.40 & 70.31 & 65.06 & 63.00 & 65.78 \\
\hline$\eta(\%)$ & 5.27 & 5.34 & 5.11 & 6.49 & 5.85 & 6.28 \\
\hline
\end{tabular}

The active area of all the DSSCs was maintained at $0.1 \mathrm{~cm}^{2}$ during these experiments.

best $J-V$ characteristics obtained for both bare $\mathrm{ZnO}$-nanorod and $\mathrm{ZnO} / \mathrm{Au}$-nanocomposite DSSCs are shown. It was found that the photocurrent of the $\mathrm{ZnO}$-nanorod DSSC improved upon the incorporation of $\mathrm{Au}$ nanoparticles in the $\mathrm{ZnO}$-nanorod photoelectrode. For the $\mathrm{ZnO} / \mathrm{Au}$-nanocomposite DSSC, $35 \%$ improvement in $J_{\mathrm{sc}}\left(14.89 \mathrm{~mA} / \mathrm{cm}^{2}\right)$ was obtained compared to the bare $\mathrm{ZnO}$-nanorod DSSC $\left(11.01 \mathrm{~mA} / \mathrm{cm}^{2}\right)$ and the overall power-conversion efficiency improved from $5.34 \%$ to $6.49 \%$.

In Figure 3b, the photocurrent responses of the bare $\mathrm{ZnO}$ nanorod and $\mathrm{ZnO} / \mathrm{Au}$-nanocomposite DSSCs measured at different incident wavelengths are shown. Due to the absorption by surface plasmons in the Au nanoparticles, an improved photocurrent response was observed above $500 \mathrm{~nm}$ illumination in the case of the $\mathrm{ZnO} / \mathrm{Au}$-nanocomposite DSSC compared to the bare $\mathrm{ZnO}$-nanorod DSSC. The $\mathrm{ZnO} / \mathrm{Au}$-nanocomposite photoelectrodes also showed slightly higher dye adsorption compared to the bare $\mathrm{ZnO}$-nanorod photoelectrode, as shown in Figure $3 \mathrm{c}$, due to the high surface area provided by the $\mathrm{Au}$ nanoparticles embedded in the surface of the $\mathrm{ZnO}$ nanorods. However, due to the only marginal improvement observed in this case, its effect on the photocurrent generation was negligible.

The improved device performance observed in the case of the $\mathrm{ZnO} / \mathrm{Au}$-nanocomposite DSSC can also be attributed to the presence of the Schottky barrier at the $\mathrm{ZnO} / \mathrm{Au}$ interface, which blocks the back electron transfer from the $\mathrm{CB}$ of $\mathrm{ZnO}$ to the $\mathrm{I}^{-} / \mathrm{I}_{3}{ }^{-}$redox electrolyte.

The formation of the Schottky barrier at the $\mathrm{ZnO} / \mathrm{Au}$ interface can be explained from the classical Schottky model, according to which a Schottky barrier forms at a semiconductor/metal junction when the work function of the metal $\left(\theta_{M}\right)$ is higher than the electron affinity of the semiconductor $\left(\chi_{S}\right)$ and the barrier height $\left(\theta_{\mathrm{SB}}\right)$ at the junction can be expressed as given in Equation 1.

$$
\theta_{\mathrm{SB}}=\theta_{\mathrm{M}}-\chi_{\mathrm{S}}
$$

In the $\mathrm{ZnO} / \mathrm{Au}$-nanocomposite system, due to the larger work function of $\mathrm{Au}(5.1 \mathrm{eV})$ [21] compared the electron affinity of $\mathrm{ZnO}(4.2 \mathrm{eV}$ ) [24], a Schottky barrier exists at their interface. However, it has been well documented that gold can form both ohmic as well as Schottky junctions with n-type $\mathrm{ZnO}$, depending on the crystal defects of $\mathrm{ZnO}[24,25]$. In this regard, Brillson and coworkers [26,27] demonstrated that by removing the surface defects of $\mathrm{ZnO}$, a $\mathrm{ZnO} / \mathrm{Au}$ ohmic junction can be converted to a Schottky junction. Therefore, in the present study, in order to ensure the formation of a Schottky barrier at the $\mathrm{ZnO} / \mathrm{Au}$ interface, the $\mathrm{ZnO} / \mathrm{Au}$ photoelectrodes were annealed at $450{ }^{\circ} \mathrm{C}$ in air for $30 \mathrm{~min}$ after the deposition of the $\mathrm{Au}$ nanoparticles in order to remove the surface defects of $\mathrm{ZnO}$.

The formation of the Schottky barrier in the $\mathrm{ZnO} / \mathrm{Au}$-nanocomposite system and the possible electron-transfer path in the $\mathrm{ZnO} / \mathrm{Au}$ DSSC is schematically represented in Figure 4. Upon irradiation, the electrons from excited dye molecules are injected into the Au nanoparticles embedded in the surface of the $\mathrm{ZnO}$ nanorods, resulting in an accumulation of electrons in the Au nanoparticle. As a result, the Fermi energy of the Au nanoparticles is pushed closer to the $\mathrm{CB}$ of the $\mathrm{ZnO}$, and the transfer of electrons from the Au nanoparticles to the $\mathrm{CB}$ of $\mathrm{ZnO}$ could occur to establish charge equilibrium in the system. Some of the electrons from the dye can also be directly injected into the $\mathrm{CB}$ of the $\mathrm{ZnO}$. In contrast, due to the existence of the Schottky barrier at the $\mathrm{ZnO} / \mathrm{Au}$ interface, electrons at the $\mathrm{CB}$ of $\mathrm{ZnO}$ cannot reverse their path, and they flow towards the oxidized dye molecules or the redox electrolyte, thus leading to an improvement in the photocurrent.

The charge-transfer mechanism in the $\mathrm{ZnO} / \mathrm{Au}$-nanocomposite system was elucidated by comparing the dynamics of the electron transfer from dye molecules to the bare $\mathrm{ZnO}$ and $\mathrm{ZnO} / \mathrm{Au}-$ nanocomposite systems through TCSPC spectroscopy. For these experiments, dye N719 was replaced by a fluorescent dye, namely Coumarin 343 (C343). Similar to dye N719, the carboxylic group of $\mathrm{C} 343$ binds directly to the $\mathrm{Zn}$ atoms on the surface of the $\mathrm{ZnO}$ nanorods [28] and has been used in DSSC 

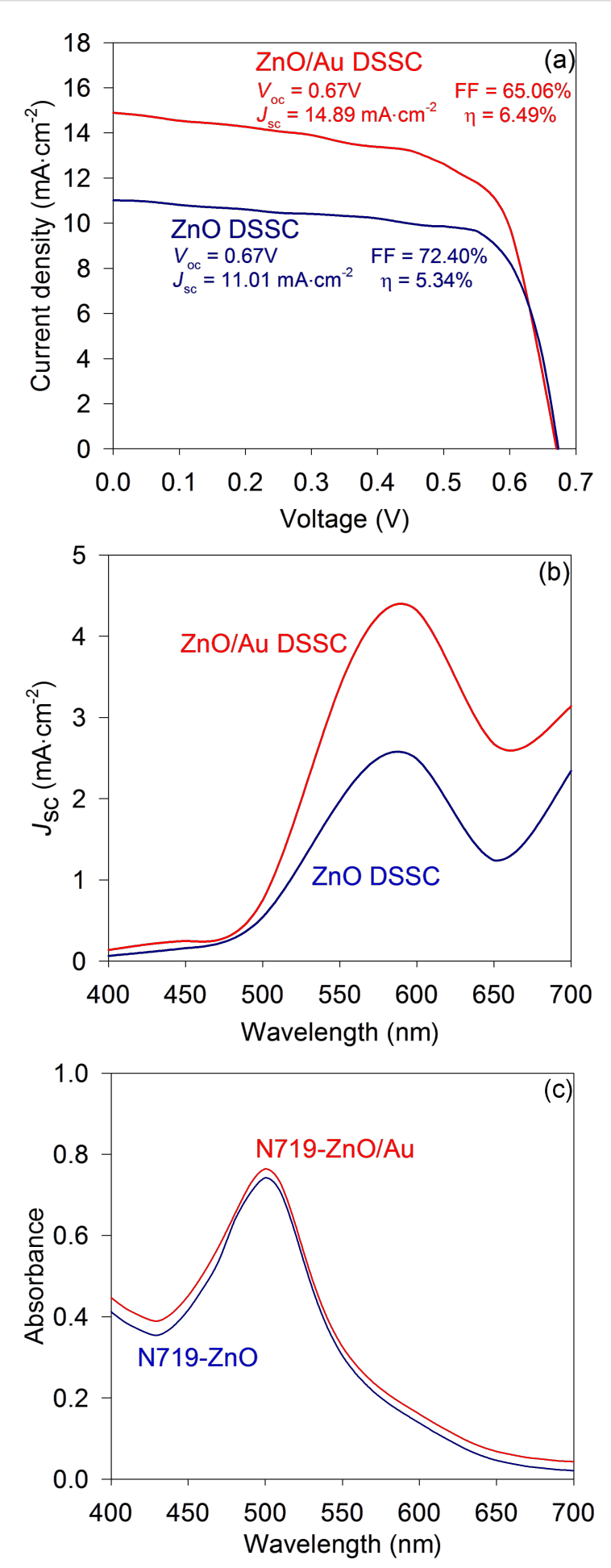

Figure 3: (a) J-V characteristics of the bare $\mathrm{ZnO}$-nanorod and ZnO/Au-nanocomposite DSSCs, measured at 1 sun, AM $1.5 \mathrm{G}$ illumination, (b) short-circuit photocurrent density of the bare ZnO-nanorod and $\mathrm{ZnO} / \mathrm{Au}$-nanocomposite DSSCs measured at different incident wavelengths and (c) optical absorptions of dye N719 in $0.1 \mathrm{mM} \mathrm{KOH}$ aqueous solution for bare $\mathrm{ZnO}$-nanorod and $\mathrm{ZnO} / \mathrm{Au}$-nanocomposite photoelectrodes. The optical absorption was measured by removing the dye molecules from the respective photoelectrodes $\left(\right.$ size $=1 \mathrm{~cm}^{2}$ ) by dipping them in a $0.1 \mathrm{mM} \mathrm{KOH}$ aqueous solution $(2 \mathrm{~mL})$ for $5 \mathrm{~min}$.

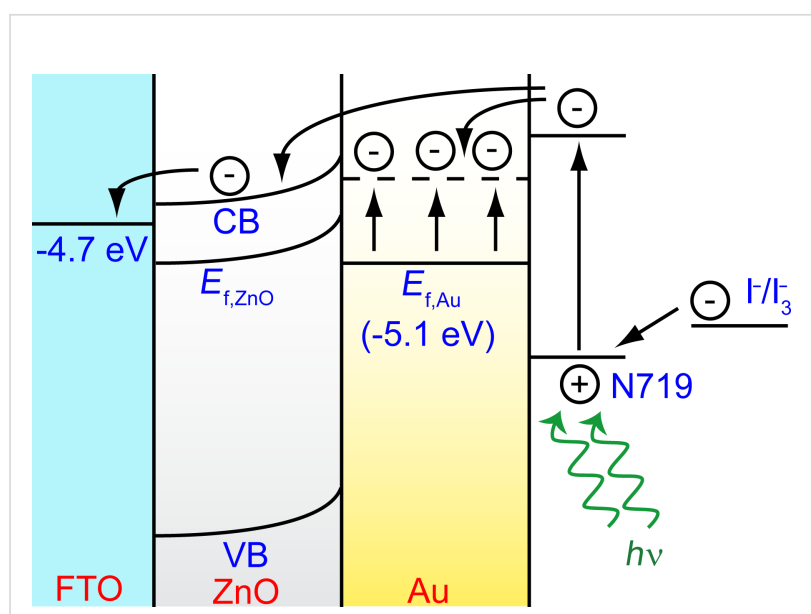

Figure 4: Energy-band diagram depicting the possible electrontransfer path in the ZnO/Au-nanocomposite DSSC, showing the Schottky barrier formed at the $\mathrm{ZnO} / \mathrm{Au}$ interface. The dashed line in $\mathrm{Au}$ represents the position of the Fermi level of gold after electron injection from dye N719.

applications [29,30]. The steady-state photoluminescence (PL) spectra of the $\mathrm{C} 343$ dye, peaking at $\sim 480 \mathrm{~nm}$, in the absence and presence of both the bare $\mathrm{ZnO}$-nanorod and $\mathrm{ZnO} / \mathrm{Au}-$ nanocomposite systems is shown in Figure 5a, where the quenching of the PL intensity of C343 dye can be clearly observed in the presence of both $\mathrm{ZnO}$ nanorods and $\mathrm{ZnO} / \mathrm{Au}$ nanocomposites. The PL transients measured at $480 \mathrm{~nm}$ (excitation at $409 \mathrm{~nm}$ ) in the presence and absence of the $\mathrm{ZnO}$-nanorod and $\mathrm{ZnO} / \mathrm{Au}$-nanocomposite systems are shown in Figure $5 \mathrm{~b}$. We observed a very sharp decay in the fluorescence intensity of the $\mathrm{C} 343$ dye in the presence of the $\mathrm{ZnO}$-nanorod or $\mathrm{ZnO} / \mathrm{Au}$ nanocomposite system. This sharp decay (nonradiative path), observed here, indicates an efficient electron transfer from the sensitizer to the semiconductor system. The various decay time constants obtained after deconvolution of the fluorescence decay curves (Figure 5b) with the instrument response function (IRF) are given in Table 3.

The fraction of electrons following the fastest decay path $\left(\tau_{3}\right.$ in Table 3) increased sharply from $26 \%$ to $94 \%$ in the presence of both $\mathrm{ZnO}$-nanorod and $\mathrm{ZnO} / \mathrm{Au}$-nanocomposite systems, confirming the presumption that efficient electron transfer from the sensitizer dye molecules to the semiconductor system takes place. We have observed similar fluorescence-decay time constants $\left(\tau_{3}\right)$ in both $\mathrm{ZnO}$-nanorod and $\mathrm{ZnO} / \mathrm{Au}$-nanocomposite systems, indicating that the dynamics of the chargetransfer process from the surface-adsorbed sensitizer to the $\mathrm{CB}$ of the semiconductor is the same in both systems. In contrast, a very low electron population in the slow decay path $\left(\tau_{1}\right.$ in Table 3 ) indicates that much less recombination of electrons occurs at the $\mathrm{C} 343$ /semiconductor interface. The longer decay 

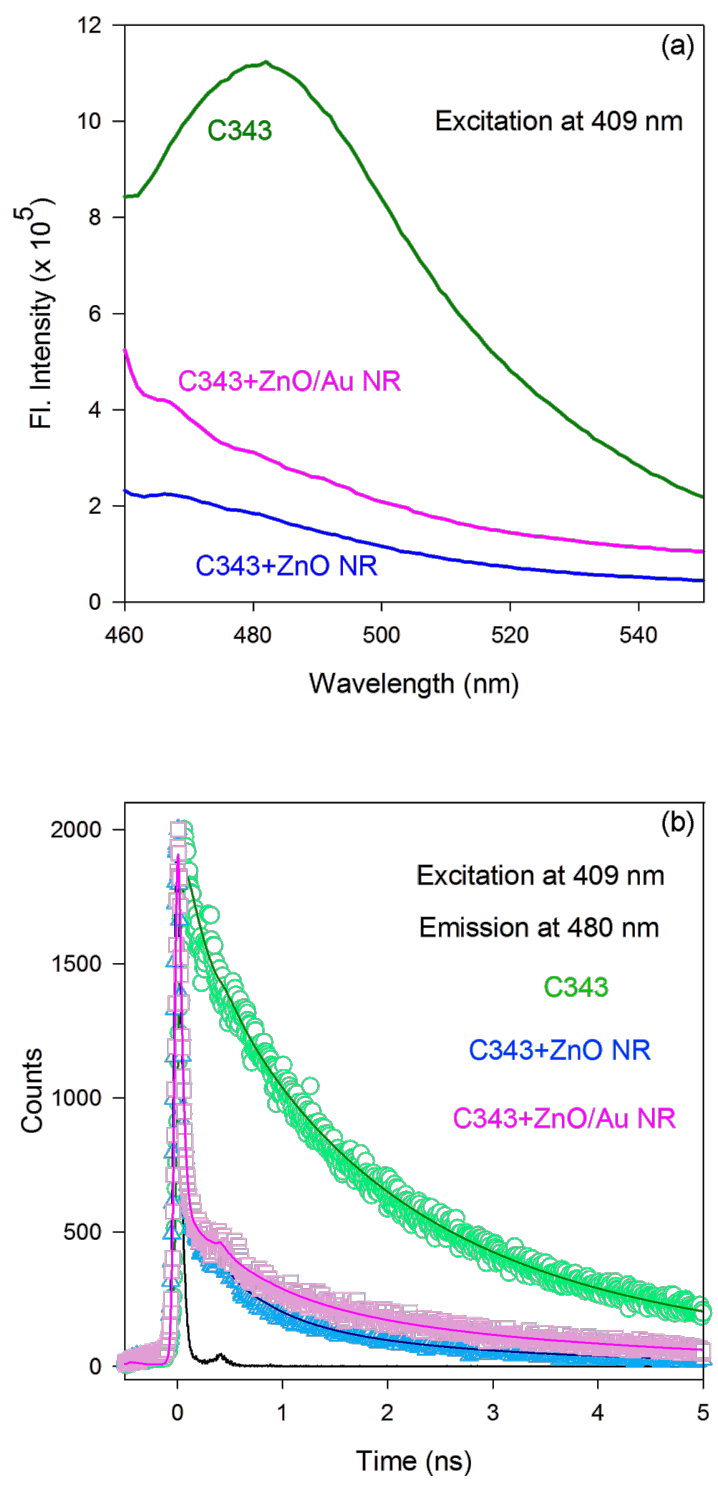

Figure 5: (a) PL spectra and (b) PL transients of the C343 dye observed at $480 \mathrm{~nm}$ in the presence and absence of bare $\mathrm{ZnO}$ nanorods and $\mathrm{ZnO} / \mathrm{Au}$ nanocomposites. The IRF was 50 ps (FWHM) and all the samples were excited at a laser wavelength of $409 \mathrm{~nm}$.
Table 3: Dynamics of picosecond-resolved luminescence transients of $\mathrm{C} 343$ dye in the presence and absence of bare $\mathrm{ZnO}$ nanorods and ZnO/Au nanocomposites. ${ }^{a}$

\begin{tabular}{lllll} 
Samples & $\mathrm{T}_{1}(\mathrm{~ns})$ & $\mathrm{T}_{2}(\mathrm{~ns})$ & $\mathrm{T}_{3}(\mathrm{~ns})$ & $\mathrm{T}_{\text {avg }}(\mathrm{ns})$ \\
\hline $\mathrm{C} 343$ & 3.866 & 1.494 & 0.191 & 1.772 \\
& $(26 \%)$ & $(48 \%)$ & $(26 \%)$ & \\
$\mathrm{C} 343+\mathrm{ZnO}$ & 2.508 & 0.560 & 0.015 & 0.087 \\
& $(2 \%)$ & $(4 \%)$ & $(94 \%)$ & \\
C343 + ZnO/Au & 3.282 & 0.691 & 0.016 & 0.134 \\
& $(3 \%)$ & $(3 \%)$ & $(94 \%)$ & \\
\hline
\end{tabular}

aThe emissions from C343 dye (probed at $480 \mathrm{~nm}$ ) were detected with a $409 \mathrm{~nm}$ laser excitation. Numbers in the parentheses indicate the relative weighting.

time constant observed in the case of the $\mathrm{ZnO} / \mathrm{Au}$-nanocomposite system (3.282 ns) compared to the bare $\mathrm{ZnO}$-nanorod system (2.508 ns) clearly indicates a longer residence time of the electrons in the nanocomposite system before their recombination. This observed longer residence time can be attributed to the presence of the Schottky barrier in the $\mathrm{ZnO} / \mathrm{Au}$-nanocomposite system, which acts as a blocking layer for the electrons in the $\mathrm{CB}$ of $\mathrm{ZnO}$ and prevents them from recombining.

The performance of the $\mathrm{ZnO} / \mathrm{Au}$-nanocomposite DSSC was further studied for solar cells with larger active areas. The $J-V$ characteristics for bare $\mathrm{ZnO}$-nanorod and $\mathrm{ZnO} / \mathrm{Au}$-nanocomposite DSSCs with active areas of $0.25 \mathrm{~cm}^{2}$ and $1 \mathrm{~cm}^{2}$ are shown in Table 4. For an active area of $0.25 \mathrm{~cm}^{2}$, the addition of Au effectively increased the $J_{\mathrm{sc}}$ of the DSSC from $7.98 \mathrm{~mA} / \mathrm{cm}^{2}$ for the bare $\mathrm{ZnO}$-nanorod DSSC to $8.61 \mathrm{~mA} / \mathrm{cm}^{2}$ for the $\mathrm{ZnO} / \mathrm{Au} \mathrm{DSSC}$. The $V_{\mathrm{oc}}$ and fill factor (FF) was also increased from $0.63 \mathrm{~V}$ to $0.66 \mathrm{~V}$ and from $47.92 \%$ to $57.53 \%$, respectively, indicating lower charge recombination at the photoelectrode due to the existence of the Schottky barrier in the $\mathrm{ZnO} / \mathrm{Au}$-nanocomposite DSSC as compared to the case of the bare $\mathrm{ZnO}$-nanorod DSSC. As a result, the overall powerconversion efficiency improved from $2.41 \%$ to $3.27 \%$.

Similar results were observed in the case of $\mathrm{ZnO}$-nanorod and $\mathrm{ZnO} / \mathrm{Au}$-nanocomposite DSSCs with an active area of $1 \mathrm{~cm}^{2}$.

Table 4: J-V characteristics of bare ZnO-nanorod and ZnO/Au-nanocomposite DSSCs with different active areas, measured at 1 sun, AM $1.5 \mathrm{G}$ illumination $\left(100 \mathrm{~mW} / \mathrm{cm}^{2}\right)$.

\begin{tabular}{|c|c|c|c|c|c|c|c|c|}
\hline \multirow{2}{*}{$\begin{array}{l}\text { DSSC active area } \\
\left(\mathrm{cm}^{2}\right)\end{array}$} & \multicolumn{4}{|c|}{ Bare ZnO-nanorod DSSC } & \multicolumn{4}{|c|}{ ZnO/Au-nanocomposite DSSC } \\
\hline & $\begin{array}{l}V_{\mathrm{OC}} \\
(\mathrm{V})\end{array}$ & $\begin{array}{l}J_{\mathrm{sc}} \\
\left(\mathrm{mA} / \mathrm{cm}^{2}\right)\end{array}$ & $\begin{array}{l}\mathrm{FF} \\
(\%)\end{array}$ & $\begin{array}{l}\eta \\
(\%)\end{array}$ & $\begin{array}{l}V_{\mathrm{OC}} \\
(\mathrm{V})\end{array}$ & $\begin{array}{l}J_{\mathrm{sc}} \\
\left(\mathrm{mA} / \mathrm{cm}^{2}\right)\end{array}$ & $\begin{array}{l}\mathrm{FF} \\
(\%)\end{array}$ & $\begin{array}{l}\eta \\
(\%)\end{array}$ \\
\hline 0.25 & 0.63 & 7.98 & 47.92 & 2.41 & 0.66 & 8.61 & 57.53 & 3.27 \\
\hline 1.00 & 0.54 & 2.25 & 41.16 & 0.50 & 0.67 & 3.80 & 45.52 & 1.16 \\
\hline
\end{tabular}


The overall power conversion efficiency (PCE) improved from $0.5 \%$ to $1.16 \%$ in the case of the $\mathrm{ZnO} / \mathrm{Au} \operatorname{DSSC}\left(J_{\mathrm{sc}}=\right.$ $3.80 \mathrm{~mA} / \mathrm{cm}^{2}, V_{\mathrm{oc}}=0.67 \mathrm{~V}$ and $\mathrm{FF}=45.52 \%$ ) compared to the bare ZnO-nanorod DSSC $\left(J_{\mathrm{sc}}=2.25 \mathrm{~mA} / \mathrm{cm}^{2}, V_{\mathrm{oc}}=0.54 \mathrm{~V}\right.$ and $\mathrm{FF}=41.16 \%$ ). The lower PCE observed in the case of the largearea DSSCs compared to the small-area DSSCs is mainly attributed to the increase in the sheet resistance of the conducting FTO substrates resulting in an overall increase in the series resistance $\left(R_{\mathrm{S}}\right)$ of the large area DSSCs, which plays an important role in the performance of the solar cell [31,32]. Table 5 shows the series resistance $\left(R_{\mathrm{S}}\right)$ of the $\mathrm{ZnO} / \mathrm{Au}$-nanocomposite DSSC for different active areas of the solar cells calculated by using a one-diode equivalent-circuit model for the DSSC as described by Murayama et al. [33,34]. It was observed that with increasing active area of the DSSCs from $0.1 \mathrm{~cm}^{2}$ to $1 \mathrm{~cm}^{2}, R_{\mathrm{S}}$ considerably increased from $5.13 \Omega$ to $27.08 \Omega$, affecting the performance of the solar cells significantly.

Table 5: Series resistance $\left(R_{\mathrm{S}}\right)$ of the $\mathrm{ZnO} / \mathrm{Au}$-nanocomposite DSSC measured for different active areas of the solar cells using a one-diode equivalent-circuit model for the DSSC.

\begin{tabular}{ll} 
ZnO/Au-DSSC active area $\left(\mathrm{cm}^{2}\right)$ & Series resistance $R_{\mathrm{S}}(\Omega)$ \\
\hline 0.10 & 5.13 \\
0.25 & 10.10 \\
1.00 & 27.08
\end{tabular}

The dependency of the device performance on the amount of $\mathrm{Au}$ nanoparticles in the photoelectrode was further studied by varying the dipping time of the $\mathrm{ZnO}$-nanorod photoelectrodes in the $0.01 \mathrm{mM} \mathrm{HAuCl}{ }_{4} \cdot \mathrm{H}_{2} \mathrm{O}$ solution from $30 \mathrm{~min}$ to $2 \mathrm{~h}$. The $J-V$ characteristics of these $\mathrm{ZnO} / \mathrm{Au}$-nanocomposite DSSCs with an active area of $1 \mathrm{~cm}^{2}$ are shown in Table 6 . On increasing the dipping time from $30 \mathrm{~min}$ to $1 \mathrm{~h}$ the overall performance of the $\mathrm{ZnO} / \mathrm{Au} \mathrm{DSSC}$ with increasing amount of $\mathrm{Au}$ nanoparticles in the photoelectrode was observed to increase. But for higher amounts of incorporated Au nanoparticles in the $\mathrm{ZnO}$-nanorod photoelectrode (upon increasing the dipping time beyond $1 \mathrm{~h}$ ) a drop in all the $J-V$ parameters was observed: The $J_{\text {sc }}$ was observed to decrease from $3.80 \mathrm{~mA} / \mathrm{cm}^{2}$ to $2.40 \mathrm{~mA} / \mathrm{cm}^{2}$, and $V_{\mathrm{oc}}$ and $\mathrm{FF}$ also dropped from $0.67 \mathrm{~V}$ and $45.52 \%$ to $0.62 \mathrm{~V}$ and $31.31 \%$, respectively, when the dipping time was increased from $1 \mathrm{~h}$ to $2 \mathrm{~h}$, resulting in a lower powerconversion efficiency, decreasing from $1.16 \%$ to $0.47 \%$.

The reduction in the DSSC performances observed with a higher amount of $\mathrm{Au}$ nanoparticles in the photoelectrode is believed to arise due to the agglomeration of the Au nanoparticles on the $\mathrm{ZnO}$-nanorod surface. With a smaller size of $\mathrm{Au}$ nanoparticles, the energy levels in $\mathrm{Au}$ are discrete and a greater
Table 6: $J-V$ characteristics of ZnO/Au-nanocomposite DSSCs with increasing amount of Au nanoparticles in the photoelectrode as a function of the dipping time of $\mathrm{ZnO}$-nanorod photoelectrodes in the $\mathrm{HAuCl}_{4} \cdot \mathrm{H}_{2} \mathrm{O}$ aq. solution $(0.01 \mathrm{mM}){ }^{\text {a }}$

\begin{tabular}{lllll}
$\begin{array}{l}\text { Dipping time } \\
(\mathrm{h})\end{array}$ & $\begin{array}{l}V_{\mathrm{OC}} \\
(\mathrm{V})\end{array}$ & $\begin{array}{l}J_{\mathrm{sc}} \\
\left(\mathrm{mA} / \mathrm{cm}^{2}\right)\end{array}$ & $\begin{array}{l}\mathrm{FF} \\
(\%)\end{array}$ & $\begin{array}{l}\eta \\
(\%)\end{array}$ \\
\hline 0.50 & 0.64 & 3.10 & 41.58 & 0.83 \\
1.00 & 0.67 & 3.80 & 45.52 & 1.16 \\
1.50 & 0.65 & 2.90 & 34.33 & 0.65 \\
2.00 & 0.62 & 2.40 & 31.31 & 0.47 \\
\hline
\end{tabular}

aThe $J-V$ characteristics were measured at 1 sun, AM $1.5 \mathrm{G}$ illumination $\left(100 \mathrm{~mW} / \mathrm{cm}^{2}\right)$ and the active area of all the DSSCs was maintained at $1 \mathrm{~cm}^{2}$ during these experiments.

shift in the Fermi levels is expected for a small electron accumulation in the Au nanoparticles [35,36]. But as Au nanoparticles agglomerate and form larger particles, more electron accumulation is required to achieve the upward shift of the Fermi level. As a result, most of the accumulated electrons from the larger Au nanoparticles recombine with the oxidized dye N719 molecules or with the $\mathrm{I}^{-} / \mathrm{I}_{3}{ }^{-}$redox electrolyte before they can be transferred to the $\mathrm{CB}$ of $\mathrm{ZnO}$, and thus this results in a poor photocurrent and low fill factor, as observed.

\section{Conclusion}

Dye-sensitized solar cells with a $\mathrm{ZnO} / \mathrm{Au}$ nanocomposite as the photoelectrode were successfully fabricated and their performances were compared with the bare $\mathrm{ZnO}$-nanorod DSSC and discussed. Incorporation of $\mathrm{Au}$ nanoparticles into the $\mathrm{ZnO}$ nanorod photoelectrode led to higher optical absorption by the photoelectrode and high dye intake, resulting in an $\sim 35 \%$ enhancement in the photocurrent in the case of the $\mathrm{ZnO} / \mathrm{Au}-$ nanocomposite DSSC (active area $=0.1 \mathrm{~cm}^{2}$ ) with $J_{\mathrm{sc}}$ equal to $14.89 \mathrm{~mA} / \mathrm{cm}^{2}$ compared to the bare $\mathrm{ZnO}$-nanorod DSSC with $J_{\text {sc }}$ equal to $11.01 \mathrm{~mA} / \mathrm{cm}^{2}$. As a result, the overall powerconversion efficiency was increased from $5.34 \%$ to $6.49 \%$ for the small-area $\left(0.1 \mathrm{~cm}^{2}\right) \mathrm{ZnO} / \mathrm{Au}$-nanocomposite DSSC. Timecorrelated single-photon count spectroscopic studies were conducted by using fluorescent Coumarin 343 dye, to explain the observed improvement in the DSSC performance in the presence of $\mathrm{Au}$ nanoparticles in the $\mathrm{ZnO}$-nanorod photoelectrode. The results showed a longer decay time of the injected electrons at the $\mathrm{CB}$ of $\mathrm{ZnO}$ in presence of $\mathrm{Au}$ nanoparticles compared to the bare $\mathrm{ZnO}$-nanorod samples, indicating a lower probability of electron recombination at the $\mathrm{ZnO} / \mathrm{Au}$ interface resulting from the blocking of back electron transfer due to the existence of the Schottky barrier at this interface. A comparable decay time constant observed for the sharp fluorescence decay path associated with the injection of the electrons from the sensitizer dye to the $\mathrm{CB}$ of $\mathrm{ZnO}$, in the presence and 
absence of Au nanoparticles, also revealed similar electrontransfer dynamics in both the bare $\mathrm{ZnO}$-nanorod and $\mathrm{ZnO} / \mathrm{Au}$ nanocomposite systems irrespective of the presence of the Schottky barrier. In the case of the large area $\mathrm{ZnO} / \mathrm{Au}$ DSSCs, efficiency dropped to $3.27 \%$ and $1.16 \%$ for active areas equal to $0.25 \mathrm{~cm}^{2}$ and $1 \mathrm{~cm}^{2}$, respectively, which was mainly attributed to the increased sheet resistance of the FTO substrates. For higher amounts of $\mathrm{Au}$ nanoparticles incorporated into the $\mathrm{ZnO}$ nanorod photoelectrode, an $\sim 60 \%$ reduction in the overall PCE of the $\mathrm{ZnO} / \mathrm{Au} \mathrm{DSSC}$ was observed, suggesting that the amount of $\mathrm{Au}$ nanoparticles in the $\mathrm{ZnO}$-nanorod photoelectrode is crucial for optimizing the performance of the $\mathrm{ZnO} / \mathrm{Au}$ nanocomposite DSSC.

\section{Experimental}

\section{Preparation of $\mathrm{ZnO} / \mathrm{Au}$-nanocomposite photoelec- trode}

All chemicals used in this study were analytical grade and were used without any further purification. Zinc acetate dihydrate $\left(\mathrm{Zn}\left(\mathrm{CH}_{3} \mathrm{COO}\right)_{2} \cdot 2 \mathrm{H}_{2} \mathrm{O}\right.$, Merck), zinc nitrate hexahydrate $\left(\mathrm{Zn}\left(\mathrm{NO}_{3}\right)_{2} \cdot 6 \mathrm{H}_{2} \mathrm{O}\right.$, Sigma-Aldrich) and hexamethylenetetramine $\left(\mathrm{C}_{6} \mathrm{H}_{12} \mathrm{~N}_{4}\right.$, Aldrich) were used as starting materials for the growth of the $\mathrm{ZnO}$ nanorods. A low-temperature hydrothermal process was used for the $\mathrm{ZnO}$-nanorod growth. Detailed processes for the hydrothermal growth of the single crystalline $\mathrm{ZnO}$ nanorods are described in our previous reports [9,37-39]. Briefly, a $1 \mathrm{mM}$ zinc acetate solution in isopropanol was used to prepare the $\mathrm{ZnO}$ seed layer on a FTO substrate followed by annealing in air at $350{ }^{\circ} \mathrm{C}$ for $5 \mathrm{~h}$. A $20 \mathrm{mM}$ aqueous solution of zinc nitrate and hexamethylenetetramine was used as a precursor solution for $\mathrm{ZnO}$-nanorod growth and the seeded FTO substrates were dipped into it at $90^{\circ} \mathrm{C}$ for $40 \mathrm{~h}$. As-grown $\mathrm{ZnO}$ nanorods on the FTO substrates were then taken out from the precursor solution and rinsed with DI water several times to remove unreacted residues from the substrate. Finally the substrates with $\mathrm{ZnO}$ nanorods were annealed at $350^{\circ} \mathrm{C}$ for $1 \mathrm{~h}$ in air.

$\mathrm{ZnO} / \mathrm{Au}$-nanocomposite photoelectrodes were prepared by in situ precipitation of $\mathrm{Au}$ nanoparticles onto the surface of the $\mathrm{ZnO}$ nanorods. The process used to synthesize the $\mathrm{Au}$ nanoparticles on the $\mathrm{ZnO}$-nanorod surface was slightly varied from the commonly followed process for the synthesis of $\mathrm{Au}$ nanoparticle colloids as described by Sugunan et al. [40]. A diluted $0.01 \mathrm{mM}$ aqueous solution of gold chloride hydrate $\left(\mathrm{HAuCl}_{4} \cdot \mathrm{H}_{2} \mathrm{O}\right.$, Aldrich) was prepared by adding $1 \mathrm{~mL}$ of $5 \mathrm{mM}$ $\mathrm{HAuCl}_{4} \cdot \mathrm{H}_{2} \mathrm{O}$ aqueous solution to $50 \mathrm{~mL}$ of DI water. The solution was then stirred for $15 \mathrm{~min}$ to mix the solute properly, and the photoelectrodes with $\mathrm{ZnO}$ nanorods were dipped into this diluted $\mathrm{HAuCl}_{4} \cdot \mathrm{H}_{2} \mathrm{O}$ solution for $1 \mathrm{~h}$. Separately, another diluted solution of $1.85 \mathrm{mM}$ of trisodium citrate (TSC,
$\mathrm{C}_{6} \mathrm{H}_{5} \mathrm{Na}_{3} \mathrm{O}_{7} \cdot 2 \mathrm{H}_{2} \mathrm{O}$, Merck) was prepared by adding $2 \mathrm{~mL}$ of $25 \mathrm{mM}$ aqueous solution of TSC to $25 \mathrm{~mL}$ of DI water under continuous stirring for $15 \mathrm{~min}$, and was used to precipitate gold nanoparticles. The photoelectrodes were then removed from the gold chloride solution and placed on a hot plate at $120{ }^{\circ} \mathrm{C}$. Aqueous TSC solution $(200 \mu \mathrm{L}, 1.85 \mathrm{mM})$ was then dropped onto the photoelectrode in order to reduce gold chloride into gold nanoparticles, and the substrate was then allowed to dry. In order to reduce the unreacted gold chloride, TSC $(200 \mu \mathrm{L})$ was added another couple of times followed by the drying sequence as explained above. Finally the photoelectrodes were cooled to room temperature and rinsed several times with DI water in order to remove any loosely attached gold nanoparticles from the $\mathrm{ZnO}$ nanorods. Subsequently the photoelectrodes were annealed at $450{ }^{\circ} \mathrm{C}$ for $30 \mathrm{~min}$ to ensure a good contact of the $\mathrm{Au}$ nanoparticles with the $\mathrm{ZnO}$ nanorods.

\section{Fabrication of dye-sensitized solar cell}

Bare $\mathrm{ZnO}$-nanorod and $\mathrm{ZnO} / \mathrm{Au}$-nanocomposite photoelectrodes were then dipped into a $0.5 \mathrm{mM}$ ethanolic solution of dye N719 and kept in the dark. Dye adsorption was carried out for $24 \mathrm{~h}$, after which the photoelectrodes were removed from the dye solution and rinsed several times with ethanol in order to remove weakly adsorbed dye molecules. The reddish photoelectrodes were then kept in the dark for about 30 min and allowed to dry at room temperature. Platinized FTO glass was used as a counter electrode. A thin platinum layer was deposited on FTOcoated glass substrates by thermal decomposition of platinum chloride $\left(\mathrm{H}_{2} \mathrm{PtCl}_{6} \cdot \mathrm{H}_{2} \mathrm{O}\right.$, Fluka $)$ at $385{ }^{\circ} \mathrm{C}$ for $15 \mathrm{~min}$. The counter electrode was then placed on top of the photoelectrode and a single layer of $50 \mu \mathrm{m}$ thick surlyn 1702 (Dupont) was used as a spacer between the two electrodes. The DSSCs were then sealed and filled with the liquid electrolyte, consisting of $0.5 \mathrm{M}$ lithium iodide (LiI), $0.05 \mathrm{M}$ iodine $\left(\mathrm{I}_{2}\right)$ and $0.5 \mathrm{M}$ 4-tertbutylpyridine (TBP) in acetonitrile (ACN), by using capillary force, through two small holes $(\phi=1 \mathrm{~mm})$ drilled on the counter electrode. Finally the two holes were sealed by using another piece of surlyn to prevent the electrolyte from leaking out of the cell.

\section{Sample preparation for the fluorescence study}

For the fluorescence study, nanorod thin films of $\mathrm{ZnO}$ and $\mathrm{ZnO} / \mathrm{Au}$ were prepared on quartz glass substrate and the dye N719 was replaced with a fluorescent dye Coumarin 343 (C343, Aldrich), since N719 is nonfluorescent in nature. A $2 \mathrm{mM}$ ethanolic solution of C343 dye was prepared and the nanorod thin films were sensitized by immersing them in the C343 solution for $1 \mathrm{~h}$. After sensitization, the films were washed with ethanol to remove weakly adsorbed dye molecules and dried under ambient conditions. 


\section{Characterization}

The characterization of the $\mathrm{ZnO}$ nanorods and Au-nanoparticlecoated $\mathrm{ZnO}$ nanorods ( $\mathrm{ZnO} / \mathrm{Au}$ nanocomposite) was performed by means of scanning electron microscopy (SEM, JEOL JSM6301F) and transmission electron microscopy (TEM, JEOL JEM-2010). Optical absorptions of the photoelectrodes were measured by using a UV-vis spectrophotometer from Ocean Optics (Micropack DH-2000) with USB4000 detector. Steadystate emission spectra were measured with a Jobin Yvon Fluoromax-3 fluorimeter (pump power at $320 \mathrm{~nm}$ is $\sim 22 \mu \mathrm{W} / \mathrm{cm}^{2}$ ). Each of the photoluminescence transients was measured by the picosecond-resolved time-correlated single-photon counting (TCSPC) technique, with a commercially available picosecond diode laser-pumped (LifeSpec-ps) time-resolved fluorescence spectrophotometer from Edinburgh Instruments, U.K. Picosecond excitation pulses from the picoquant diode laser were used at $409 \mathrm{~nm}$ with an instrument response function (IRF) of 50 ps. A microchannel plate photomultiplier tube (MCP-PMT, Hammamatsu) was used to detect the photoluminescence from the sample after dispersion through a monochromator. For all transients, the polarizer on the emission side was adjusted to be at $55^{\circ}$ (the "magic angle") with respect to the polarization axis of the excitation beam. Measurements of the DSSC $J-V$ characteristics were performed under 1 sun, AM $1.5 \mathrm{G}$ (air mass 1.5 global, $100 \mathrm{~mW} / \mathrm{cm}^{2}$ ) illumination by using a $150 \mathrm{~W}$ small-beam solar simulator (Sciencetech, model SF150) as a light source and a Keithley 617 programmable electrometer as a voltage source.

\section{Acknowledgements}

T. Bora would like to acknowledge financial support from the Sheikh Saqr Al Qasimi Graduate Research Fellowship, and H. H. Kyaw thanks the Centre of Excellence in Nanotechnology at the Asian Institute of Technology partially funded by the National Nanotechnology Center (NANOTEC) of the National Science \& Technology Development Agency (NSTDA) of the Royal Thai Government, for supporting this research work. S. Sarkar would like to thank UGC fellowship for financial support.

\section{References}

1. O'Regan, B.; Grätzel, M. Nature 1991, 353, 737-740. doi:10.1038/353737a0

2. Grätzel, M. J. Photochem. Photobiol., A 2004, 164, 3-14. doi:10.1016/j.jphotochem.2004.02.023

3. Grätzel, M. J. Photochem. Photobiol., C 2003, 4, 145-153. doi:10.1016/S1389-5567(03)00026-1

4. Nazeeruddin, M. K.; De Angelis, F.; Fantacci, S.; Selloni, A.; Viscardi, G.; Liska, P.; Ito, S.; Takeru, B.; Grätzel, M. J. Am. Chem. Soc. 2005, 127, 16835-16847. doi:10.1021/ja052467।

5. Law, M.; Greene, L. E.; Johnson, J. C.; Saykally, R.; Yang, P. Nat. Mater. 2005, 4, 455-459. doi:10.1038/nmat1387
6. Yang, P.; Yan, H.; Mao, S.; Russo, R.; Johnson, J.; Saykally, R.; Morris, N.; Pham, J.; He, R.; Choi, H. J. Adv. Funct. Mater. 2002, 12, 323-331. doi:10.1002/1616-3028(20020517)12:5<323::AID-ADFM323>3.0.CO;2$\mathrm{G}$

7. Xia, J. B.; Zhang, X. W. Eur. Phys. J. B 2006, 49, 415-420. doi:10.1140/epjb/e2006-00093-1

8. Quintana, M.; Edvinsson, T.; Hagfeldt, A.; Boschloo, G. J. Phys. Chem. C 2007, 111, 1035-1041. doi:10.1021/jp065948f

9. Baruah, S.; Dutta, J. Sci. Technol. Adv. Mater. 2009, 10, 013001. doi:10.1088/1468-6996/10/1/013001

10. Nazeeruddin, M. K.; Kay, A.; Rodicio, I.; Humphry-Baker, R.; Müller, E.; Liska, P.; Vlachopoulos, N.; Grätzel, M. J. Am. Chem. Soc. 1993, 115, 6382-6390. doi:10.1021/ja00067a063

11. Haque, S. A.; Tachibana, Y.; Willis, R. L.; Moser, J. E.; Grätzel, M.; Klug, D. R.; Durrant, J. R. J. Phys. Chem. B 2000, 104, 538-547. doi:10.1021/jp991085x

12. Wang, P.; Zakeeruddin, S. M.; Moser, J. E.; Grätzel, M. J. Phys. Chem. B 2003, 107, 13280-13285. doi:10.1021/jp0355399

13. Gregg, B. A.; Pichot, F.; Ferrere, S.; Fields, C. L. J. Phys. Chem. B 2001, 105, 1422-1429. doi:10.1021/jp003000u

14. Palomares, E.; Clifford, J. N.; Haque, S. A.; Lutz, T.; Durrant, J. R. J. Am. Chem. Soc. 2003, 125, 475-482. doi:10.1021/ja027945w

15. Greene, L. E.; Law, M.; Yuhas, B. D.; Yang, P. J. Phys. Chem. C 2007, 111, 18451-18456. doi:10.1021/jp077593।

16. Wang, M.; Huang, C.; Cao, Y.; Yu, Q.; Deng, Z.; Liu, Y.; Huang, Z.; Huang, J.; Huang, Q.; Guo, W.; Liang, J. J. Phys. D: Appl. Phys. 2009, 42, 155104. doi:10.1088/0022-3727/42/15/155104

17. Zhang, X. T.; Sutanto, I.; Taguchi, T.; Tokuhiro, K.; Meng, Q. B.; Rao, T. N.; Fujishima, A.; Watanabe, H.; Nakamori, T.; Uragami, M. Sol. Energy Mater. Sol. Cells 2003, 80, 315-326. doi:10.1016/j.solmat.2003.08.006

18. Law, M.; Greene, L. E.; Radenovic, A.; Kuykendall, T.; Liphardt, J.; Yang, P. J. Phys. Chem. B 2006, 110, 22652-22663. doi:10.1021/jp0648644

19. Barazzouk, S.; Hotchandani, S. J. Appl. Phys. 2004, 96, 7744-7746. doi:10.1063/1.1811775

20. Mikroyannidis, J. A.; Stylianakis, M. M.; Suresh, P.; Roy, M. S.; Sharma, G. D. Energy Environ. Sci. 2009, 2, 1293-1301. doi:10.1039/B915235K

21. Chen, Z. H.; Tang, Y. B.; Liu, C. P.; Leung, Y. H.; Yuan, G. D.; Chen, L. M.; Wang, Y. Q.; Bello, I.; Zapien, J. A.; Zhang, W. J.; Lee, C. S.; Lee, S. T. J. Phys. Chem. C 2009, 113, 13433-13437. doi:10.1021/jp903153w

22. Chou, C. S.; Yang, R. Y.; Yeh, C. K.; Lin, Y. J. Powder Technol. 2009, 194, 95-105. doi:10.1016/j.powtec.2009.03.039

23. Su, Y. H.; Lai, W. H.; Teoh, L. G.; Hon, M. H.; Huang, J. L. Appl. Phys. A: Mater. Sci. Process. 2007, 88, 173-178. doi:10.1007/s00339-007-3988-7

24. Brillson, L. J.; Yicheng, L. J. Appl. Phys. 2011, 109, 121301. doi:10.1063/1.3581173

25. Ip, K.; Thaler, G. T.; Yang, H.; Han, S. Y.; Li, Y.; Norton, D. P.; Pearton, S. J.; Jang, S.; Ren, F. J. Cryst. Growth 2006, 287, 149-156. doi:10.1016/j.jcrysgro.2005.10.059

26. Brillson, L. J.; Mosbacker, H. L.; Hetzer, M. J.; Strzhemechny, Y.; Look, D. C.; Cantwell, G.; Zhang, J.; Song, J. J. Appl. Surf. Sci. 2008, 254, 8000-8004. doi:10.1016/j.apsusc.2008.03.050

27. Brillson, L. J.; Mosbacker, H. L.; Hetzer, M. J.; Strzhemechny, Y.; Jessen, G. H.; Look, D. C.; Cantwell, G.; Zhang, J.; Song, J. J. Appl. Phys. Lett. 2007, 90, 102116. doi:10.1063/1.2711536 
28. Duncan, W. R.; Prezhdo, O. V. Annu. Rev. Phys. Chem. 2007, 58, 143-184. doi:10.1146/annurev.physchem.58.052306.144054

29. Hara, K.; Sayama, K.; Ohga, Y.; Shinpo, A.; Suga, S.; Arakawa, H. Chem. Commun. 2001, 569-570. doi:10.1039/b010058g

30. Zhang, X.; Zhang, J. J.; Xia, Y. Y. J. Photochem. Photobiol., A 2008, 194, 167-172. doi:10.1016/j.jphotochem.2007.08.004

31. Onoda, K.; Ngamsinlapasathian, S.; Fujieda, T.; Yoshikawa, S. Sol. Energy Mater. Sol. Cells 2007, 91, 1176-1181. doi:10.1016/j.solmat.2006.12.017

32. Denhoff, M. W.; Drolet, N. Sol. Energy Mater. Sol. Cells 2009, 93, 1499-1506. doi:10.1016/j.solmat.2009.03.028

33. Murayama, M.; Mori, T. Thin Solid Films 2006, 509, 123-126. doi:10.1016/j.tsf.2005.09.145

34. Murayama, M.; Mori, T. Equivalent circuit analysis of dye-sensitized solar cell fabricated at low-temperature. In Proceedings of the International Symposium on Electrical Insulating Materials ISEIM 2008, Yokkaichi, Japan, Sept 7-11, 2008; IEEE Publishing: Piscataway, NJ, 2008; pp 251-254. doi:10.1109/ISEIM.2008.4664543

35. Kamat, P. V. J. Phys. Chem. C 2008, 112, 18737-18753. doi:10.1021/jp806791s

36. Haruta, M. Catal. Today 1997, 36, 153-166. doi:10.1016/S0920-5861(96)00208-8

37. Baruah, S.; Dutta, J. J. Sol-Gel Sci. Technol. 2009, 50, 456-464. doi:10.1007/s10971-009-1917-2

38. Baruah, S.; Dutta, J. J. Cryst. Growth 2009, 311, 2549-2554. doi:10.1016/j.jcrysgro.2009.01.135

39. Sugunan, A.; Warad, H. C.; Boman, M.; Dutta, J. J. Sol-Gel Sci. Technol. 2006, 39, 49-56. doi:10.1007/s10971-006-6969-y

40. Sugunan, A.; Dutta, J. MRS Online Proceedings Library 2005, 901 , 257-262. doi:10.1557/PROC-0901-Ra16-55-Rb16-55

\section{License and Terms}

This is an Open Access article under the terms of the Creative Commons Attribution License (http://creativecommons.org/licenses/by/2.0), which permits unrestricted use, distribution, and reproduction in any medium, provided the original work is properly cited.

The license is subject to the Beilstein Journal of Nanotechnology terms and conditions:

(http://www.beilstein-journals.org/bjnano)

The definitive version of this article is the electronic one which can be found at: doi:10.3762/bjnano.2.73 